\title{
Analyzing the operational conditions of crash carts in clinical and surgical hospitalization units
}

\author{
Análise das condições operacionais de carros de emergência \\ em unidades de internação clínica e cirúrgica \\ Análisis de las condiciones de funcionamiento de los carros de paradas \\ en las unidades de hospitalización clínica y quirúrgica
}

How to cite this article:

Silva VF, Lazzari DD, Reisdorfer N, Michaelsen SC, Kuhnen AE. Analyzing the operational conditions of crash carts in clinical and surgical hospitalization units. Rev Esc Enferm USP. 2021;55:e03693. doi: https://doi.org/10.1590/S1980-220X2019040003693

\author{
D Vanessa Fortes da Silva ${ }^{1}$ \\ Daniele Delacanal Lazzari² \\ Nara Reisdorfer ${ }^{3}$ \\ Simara Claudia Michaelsen ${ }^{4}$ \\ iD Adriana Eich Kuhnen ${ }^{4}$ \\ 1 Hospital Governador Celso Ramos, \\ Florianópolis, SC, Brazil. \\ ${ }^{2}$ Universidade Federal de Santa \\ Catarina, Departamento de Enfermagem, \\ Florianópolis, SC, Brazil. \\ ${ }^{3}$ Hospital Regional Dr. Homero de Miranda \\ Gomes, Florianópolis, SC, Brazil. \\ ${ }^{4}$ Hospital Universitário Polydoro Ernani \\ de São Thiago, Florianópolis, SC, Brazil.
}

Corresponding author:

Daniele Delacanal Lazzari

Universidade Federal de Santa Catarina,

Centro de Ciências da Saúde

Departamento de Enfermagem

Rua Delfino Conti s/n. Bloco I, Sala 314

CEP 88040-370 - Florianópolis, SC, Brazil

daniele.lazzari@ufsc.br

\begin{abstract}
Objective: To evaluate the operational conditions of crash carts in all clinical and surgical hospitalization units of public hospitals in a region in Southern Brazil. Method: Quantitative, cross-sectional study to evaluate crash carts in adult clinical and surgical hospitalization units. The data were collected through a checklist containing 16 continuous variables. Results: Nineteen crash carts in nineteen units were evaluated. Analysis shows that the most frequent problems were excess of equipment and its lack of organization, medication in incorrect compartments and/or with no identification, and inappropriate environment for transportation. Conclusion: The most relevant factors that possibly interfere with the operational conditions of crash carts are directly related to the organization and management of material resources, which may lead to the reduction of its functionality during patient care. Such problem may be solved by readjusting items and performing frequent verification.
\end{abstract}

\section{DESCRIPTORS}

Heart Arrest; Cardiopulmonary Resuscitation; Emergency Nursing; Equipment and Supplies. 


\section{INTRODUCTION}

Cardiopulmonary arrest (CPA) consists of the interruption of circulatory and respiratory functions, leading to irreversible brain injuries and death if the patient is not immediately cared for. Time until this complication is treated is the primordial factor for patient prognosis: every minute without intervention is estimated to reduce survival odds by $10 \%^{(1)}$. This is thus considered one the severest clinical emergencies.

Treating CPA in the hospital environment requires the multiprofessional team to be quick in recognizing clinical signs and starting Cardiopulmonary Resuscitation (CPR) maneuvers ${ }^{(2)}$. The availability of equipment and medication for patient assistance is crucial during this event; these are provided through a mobile cabinet called Crash Cart (CC), which must be present in all hospital units.

The CC includes medication and equipment used for treating CPA. Its standardization in Brazil was proposed by the Brazilian Cardiology Society (Sociedade Brasileira de Cardiologia-SBC), guided mainly by directives from the American Heart Association (AHA) (3). Such standardization aimed at homogenizing the content and number of available items to organize and provide only what is needed to reduce the time of response to treatment and avoid wasting equipment ${ }^{(4)}$.

The lack of identification in equipment and medications, their disorganization and excess or scarcity of equipment in the $\mathrm{CC}$ makes it harder to visualize items quickly, interfering with the treatment and compromising patient safety. In ideal conditions, when dealing with the $\mathrm{CC}$ and opening its drawers, it should be possible to see all the items to, in a few seconds, select the ones which are necessary for treatment ${ }^{(4)}$. This applies mainly to the medication and solutions drawer since a mistaken administration of intravenous solutions may, among others, lead to irreversible damage or even patient death ${ }^{(5)}$.

Safety is considered a basic principle in health assistance and may be defined as the reduction of risk of unnecessary damage associated to healthcare in face of potential damage ${ }^{(6)}$. A study conducted in Brazil on how nursing teams treat CPA has shown, in part of the observed cases, the team's difficulty in finding the equipment in the $\mathrm{CC}^{(7)}$. These data reinforce the importance of standardization, of drawer identification, and of maintaining only what is necessary inside the $\mathrm{CC}$, avoiding waste of material resources and reducing time for accessing the items while promoting actions for patient safety ${ }^{(8)}$.

In hospital units, the responsibility of organizing and maintaining the $\mathrm{CC}$ lies on the nurse, who is the technical responsible for assembling, checking, and replacing equipment and medication. It is mandatory to check the seal and the blades for tracheal intubation, perform defibrillator tests, verify the amount of oxygen in the cylinder, and other items or aspects which guarantee the CC's daily functionality ${ }^{(9-10)}$.

Thus, considering that this is a fundamental item for CPA treatment, whose responsibility for organization and maintenance is the nurse's, the $\mathrm{CC}$ is also an important element in the promotion of safe care, which is part of patients' right to the best service, an ethical compromise of Nursing. With the objective of analyzing the conditions of the crash carts for safe and effective treatment to patients during CPA, the following question is posed: what are the operational conditions of crash carts in clinical and surgical hospitalization units in public hospitals? To provide an answer, the general objective was analyzing the operational conditions of crash carts in clinical and surgical hospitalization units.

\section{METHOD}

\section{Study DESIGN}

Quantitative, cross-sectional, exploratory-descriptive study.

\section{SCENARIO}

Adult clinical and surgical units of public hospitals in the metropolitan region of a municipality in Southern Brazil. Such region has 22 municipalities and nine medium and large sized hospitals.

Hospitalization units are hospital wards for patients who require direct health assistance for longer than 24 hours. These units are divided by age group, gender, pathology, and intensity of care. The hospitalization units approached in this study include clinical and surgical specialties and have the same level of intensity of care (low and medium complexity).

\section{SelECTION CRITERIA}

The following were inclusion criteria: public hospitals in the above-mentioned area, in a municipality with more than 150 thousand inhabitants and possessing more than 100 hospitalization beds. The exclusion criteria were hospital units undergoing reform or temporarily closed. Four hospitals met the established inclusion criteria. With reforms in some hospital institutions, the total number of units was 19. Since each unit is required to have one $\mathrm{CC}$, the sample totaled 19 carts.

\section{Data collection}

Data collection was conducted in the period between January and April 2019 in shifts and hours chosen by nurses who were responsible for the sectors. A checklist created for this study was employed. It was based on the literature and the researchers' experience and included recommendations by Sociedade Brasileira de Cardiologia ${ }^{(3)}$. When irregularities in the items available in the $\mathrm{CC}$ were found, the nurses responsible for the unit were notified. In addition to indispensable items, aspects concerning conservation, maintenance, organization, cleanliness, and mobility, considered key points for performance in treating CPA, were observed. Each CC was evaluated only once.

\section{Data ANALISSIS AND treatment}

The data were tabulated into a Microsoft Excel ${ }^{\circledR}$ spreadsheet and descriptively analyzed. Sixteen continuous variables were considered. These corresponded to the analysis of operational conditions and to the inadequacy of items chosen for evaluation, as shown in Chart 1. 
Chart 1 - Checklist items for evaluating crash carts in clinical and surgical units and inadequacy conditions according to hospital standards and in-site evaluation.

\begin{tabular}{|c|c|}
\hline Checklist items & Evaluation of operational conditions/Inadequacy \\
\hline 1. Standardization per SBC norms & Lack of standardization \\
\hline 2. Easiness of transportation & Environment with obstacles for transportation (chair, stretcher, etc.) or narrow passageway \\
\hline 3. Maintenance conditions & $\begin{array}{l}\text { Wheel problems which impaired mobility; } \\
\text { difficulty in opening drawers }\end{array}$ \\
\hline 4. External cleanliness & Visible dirtiness, presence of insects \\
\hline 5. Hygiene conditions of intubation equipment & Presence of residues and lack of identification \\
\hline 6. Seal integrity & Violated or absent seal or use of a padlock \\
\hline 7. Amount of equipment & One or more pieces of equipment in addition to the recommended \\
\hline 8. Drawer size & Drawers which could not hold the indicated amount of equipment \\
\hline 9. Checklist for defibrillator test & Absent \\
\hline 10. Defibrillator connected to power line & Off \\
\hline 11. Medication's expiration date & Expired medicine \\
\hline 12. Medication organization & Medication in the wrong drawer compartment or with no identified compartment \\
\hline 13. Mannitol conditions & Solution with any crystallization level \\
\hline 14. Nurse trained for using the defibrillator & Impossibility verbalized by the nurse when conducting defibrillator test \\
\hline 15. Presence of hand resuscitator & Absence of resuscitator \\
\hline 16. Presence of hard board & Absence of hard board \\
\hline
\end{tabular}

\section{ETHICAL ASPECTS}

Authorization from the direction of each participating hospital was required for this study. The research project was approved by the Research Ethics Committee of Universidade Federal de Santa Catarina under Opinion number 3.101.520/2018. The instrument for data collection was applied after consent from such committee, following the orientations of Resolution number 466/2012, by the National Health Council, on research involving human subjects. All nurses responsible for the units, which supervised the opening/evaluation of the $\mathrm{CC}$, have signed the Informed Consent Form (ICF).

\section{RESULTS}

The nurses' education was not evaluated, because these were a small fraction of the nurses in the hospitalization units and were not necessarily responsible for the seal during data collection or for organizing the cart in their shift (in the case of shifts and units with more than one nurse on duty at the same time). Given that collection occurred in four different hospitals, the organization and the number of nursing personnel in the units varied enormously; and this was not the objective of the analysis departing from the research question.

The four hospitals and the nineteen hospitalization units were distributed as in Table 1.

To analyze operational conditions, the data were collected in situ through an evaluation of the crash carts in the hospitalization units authorized by the nursing management, as shown in Table 2. The carts were analyzed in the presence of nurses who were responsible for them in their shifts.
Table 1 - Distribution of hospitals and hospitalization units regarding service profile and number of beds - Florianópolis, SC, Brazil, 2019.

\begin{tabular}{|c|c|c|c|}
\hline Hospital & Units & $\begin{array}{l}\text { Number } \\
\text { of beds }\end{array}$ & Profile \\
\hline \multirow{5}{*}{ A } & $\mathrm{A} 1$ & 23 & $\begin{array}{c}\text { Clinical and surgical conditions, } \\
\text { isolation }\end{array}$ \\
\hline & $\mathrm{A} 2$ & 29 & Clinical conditions \\
\hline & A3 & 30 & Surgical conditions \\
\hline & A4 & 30 & Surgical conditions \\
\hline & A5 & 06 & Clinical and surgical gynecology \\
\hline \multirow{5}{*}{ B } & B6 & 18 & Surgical conditions \\
\hline & B7 & 48 & $\begin{array}{c}\text { Clinical and surgical conditions, } \\
\text { isolation }\end{array}$ \\
\hline & B8 & 16 & Surgical neurology \\
\hline & B9 & 20 & Clinical neurology \\
\hline & B10 & 10 & Clinical conditions \\
\hline C & $\begin{array}{l}\text { C11 } \\
\text { C12 } \\
\text { C13 } \\
\text { C14 } \\
\text { C15 }\end{array}$ & $\begin{array}{l}22 \\
11 \\
15 \\
18 \\
06\end{array}$ & $\begin{array}{l}\text { Pneumology } \\
\text { Infectiology } \\
\text { Infectiology } \\
\text { Phthisiology } \\
\text { Infectiology }\end{array}$ \\
\hline \multirow{4}{*}{ D } & D16 & 33 & Clinical conditions \\
\hline & D17 & 33 & $\begin{array}{c}\text { Clinical conditions, surgical } \\
\text { conditions }\end{array}$ \\
\hline & D18 & 40 & Surgical conditions \\
\hline & D19 & 42 & Surgical conditions \\
\hline
\end{tabular}


Table 2 - Analysis of the operational conditions of crash carts in 19 adult medical and surgical hospitalization units - Florianópolis, SC, Brazil, 2019.

\begin{tabular}{|c|c|c|}
\hline Variable & n (\%) & $\mathbf{n}$ \\
\hline \multicolumn{3}{|c|}{$\begin{array}{l}\text { 1. Standards according to Sociedade } \\
\text { Brasileira de Cardiologia }\end{array}$} \\
\hline $\begin{array}{l}\text { Appropriate } \\
\text { Inappropriate }\end{array}$ & $\begin{array}{l}52.6 \% \\
47.4 \% \\
\end{array}$ & $\begin{array}{c}10 \\
9\end{array}$ \\
\hline \multicolumn{3}{|c|}{ 2. Transportation easiness } \\
\hline $\begin{array}{l}\text { Appropriate } \\
\text { Inappropriate }\end{array}$ & $\begin{array}{l}36.8 \\
63.2\end{array}$ & $\begin{array}{c}7 \\
12\end{array}$ \\
\hline \multicolumn{3}{|c|}{ 3. Maintenance conditions } \\
\hline $\begin{array}{l}\text { Appropriate } \\
\text { Inappropriate }\end{array}$ & $\begin{array}{l}73.7 \\
26.3\end{array}$ & $\begin{array}{c}14 \\
5\end{array}$ \\
\hline \multicolumn{3}{|c|}{ 4. External cleanliness } \\
\hline $\begin{array}{l}\text { Appropriate } \\
\text { Inappropriate }\end{array}$ & $\begin{array}{l}84.2 \\
15.8\end{array}$ & $\begin{array}{c}16 \\
3\end{array}$ \\
\hline \multicolumn{3}{|c|}{$\begin{array}{l}\text { 5. Hygiene conditions of intubation } \\
\text { equipment }\end{array}$} \\
\hline $\begin{array}{l}\text { Appropriate } \\
\text { Inappropriate }\end{array}$ & $\begin{array}{l}73.7 \\
26.3\end{array}$ & $\begin{array}{c}14 \\
5\end{array}$ \\
\hline \multicolumn{3}{|c|}{ 6. Seal integrity } \\
\hline $\begin{array}{l}\text { Appropriate } \\
\text { Inappropriate }\end{array}$ & $\begin{array}{l}84.2 \\
15.8 \\
\end{array}$ & $\begin{array}{c}16 \\
3\end{array}$ \\
\hline \multicolumn{3}{|c|}{ 7. Amount of equipment } \\
\hline $\begin{array}{l}\text { Appropriate } \\
\text { Inappropriate }\end{array}$ & $\begin{array}{l}36.8 \\
63.2\end{array}$ & $\begin{array}{c}7 \\
12\end{array}$ \\
\hline
\end{tabular}

8. Drawer size

\begin{tabular}{lcc} 
Appropriate & 94.7 & 18 \\
Inappropriate & 5.3 & 1 \\
\hline
\end{tabular}

9. Checklist for the defibrillator test

\begin{tabular}{lcc} 
Appropriate & 68.4 & 13 \\
Inappropriate & 31.6 & 6 \\
\hline 10. Defibrillator connected to power line & & \\
& & 13 \\
Appropriate & 68.4 & 6 \\
Inappropriate & 31.6 & \\
\hline
\end{tabular}

11. Medication expiration date

\begin{tabular}{lcc} 
Appropriate & 84.2 & 16 \\
Inappropriate & 15.8 & 3 \\
\hline
\end{tabular}

12. Medication organization

\begin{tabular}{lcc} 
Appropriate & 47.4 & 9 \\
Inappropriate & 52.6 & 10 \\
\hline 13. Mannitol conditions & & \\
& & 9 \\
Appropriate & 47.4 & 10 \\
Inappropriate & 52.7 & \\
\hline
\end{tabular}

14. Nurse trained for defibrillator test

\begin{tabular}{lcc} 
Appropriate & 47.4 & 9 \\
Inappropriate & 52.6 & 10 \\
\hline 15. Presence of hand resuscitator & & \\
& & 18 \\
Appropriate & 94.7 & 1 \\
Inappropriate & 5.3 & \\
\hline 16. Presence of hard board & & 18 \\
Appropriate & 94.7 & 1 \\
Inappropriate & 5.3 & \\
\hline
\end{tabular}

The conditions of the $\mathrm{CC}$ were considered appropriate in 11 out of the 16 evaluated items. Other situations faced at the collection moment were: $\mathrm{CC}$ is in an area too narrow to pass, making it difficult to move, and presence of obstacles, such as oxygen cylinder, stretcher, table, and chair. Other situations observed included: drawers would not open completely, hindering item visualization, and swivel casters with low rotation capacity, reducing mobility.

In the item External cleanliness, three (10.5\%) carts were considered inappropriate. When checking $\mathrm{CCs}$, residues of a blood-like substance were observed in the external part of a cart, in addition to dirt in another one. Also, insects were observed in all the external extension of yet another cart. Also concerning variables related to cleanliness conditions, five $(26.3 \%)$ carts were considered inappropriate regarding the item Hygiene conditions of intubation equipment. This equipment had insects or was protected by visibly dirty fabric or stored in a case with dirt inside.

In two of the observed units, the cart was protected with a padlock, not a plastic seal and, in one of these units, at the moment of data collection, the team took approximately 10 minutes to find the padlock key. In a third unit, the plastic seal was available, but breaking it to open the cart was not necessary, due to a flaw in its structure.

Excessive amount of equipment for vascular access puncture (syringes, needles, intravenous peripheric catheter, micropore, and physiological serum $0.9 \%$ ) was also frequent during data collection. In a CC, 37 needles of three distinct gauges were observed, even though the institutional protocol suggested five units of each.

In the item Medication expiration date, three (15.8\%) of the CCs contained expired medication and 10 (52.6\%) of the CCs were considered inappropriate regarding the variable Medication organization, since diverse priority one medications (atropine, adrenaline, amiodarone, etc.) were found in the wrong compartments, while others did not present due identification.

\section{DISCUSSION}

The specialties of the participating units included general clinical hospitalization, general surgical, clinical and surgical gynecology, clinical and surgical neurology, pneumology and infectiology. A significant part of the CC sample was considered appropriate, which indicates that recommendations have been complied with, which is shown, for example, by the expiration dates of medications and their availability, which are contributing factors to patient care safety.

Considering that part of the sample did not comply with SBC's norms, crash cart standardization in the hospital units must be emphasized as fundamental to patient safety. SBC's First Guideline on Cardiopulmonary Resuscitation and Emergency Cardiovascular Care suggests a standardization model based on the AHA's norms. SBC emphasizes that standardization should take the specificity of each hospital/ unit into account ${ }^{(11)}$.

The CC was conceived so that equipment and medications would be immediately available for use, since emergencies, even in hospital environments, can generate a sensation 
of chaos among the team, and the fact that equipment are not readily available for use may amplify this feeling and hinder assistance ${ }^{(4)}$.

In units whose standardization was proposed by the hospital, a better organization of equipment and a reduction in items other than those recommended as level 1 or 2 by the $\mathrm{SBC}$ was observed. The time spent performing verifications in standardized units was smaller in relation to units with no standardization.

In relation to the variable Transportation easiness, part of the CCs was observed not to be in appropriate conditions. Even though SBC suggests in its guideline for cardiopulmonary resuscitation that $\mathrm{CC}$ s must be moved quickly, it was still possible to find an expressive number of units where mobility is reduced regarding physical space and obstacles along the way ${ }^{(11)}$

To be used appropriately, it is highly important for $\mathrm{CCs}$ in the unit to be positioned in a broad area which can be easily accessed, so as to facilitate its movement to the place of treatment ${ }^{(12-13)}$. Although obstacles are commonly unnoticed, it is important to emphasize that CPA is a stressful situation for the whole team, and appropriate infrastructure is required for moving equipment and personnel. Any delay in taking the $\mathrm{CC}$ to the bed/place where the patient is contributes to put patient safety at risk ${ }^{(14)}$. A central justification for the importance of moving the $\mathrm{CC}$ as quickly as possible is the relation between the time in which CPA starts and the start of defibrillation (in shockable rhythms). Every minute of delayed defibrillation is estimated to reduce survival odds in 10\%; after 10 minutes, survival odds are minimal ${ }^{(15)}$.

Regarding the item Maintenance Conditions, five (26.3\%) carts were considered inappropriate. This is one of the contributing factors for the delay in time of response to patient aggravation ${ }^{(14,16)}$. Regarding external cleanliness, surface regions (such as the external area of $\mathrm{CCs}$ ) are means for pathogen dissemination when due cleaning and disinfection are not performed ${ }^{(17)}$. The different routines of cleaning/ disinfection, such as concurrent and terminal, should be performed once a day for the CC's external part, the defibrillator and the laryngoscope, whereas the second should be conducted only in the external and internal part of the $\mathrm{CC}$, once a month ${ }^{(13)}$.

Regarding protection of medication and equipment in the CC, plastic seals with a serial number make it possible to register and control the moments in which the $\mathrm{CC}$ is opened. Also, its opening does not require a key, since it is enough to pull the seal to open ${ }^{(12)}$. Thus, in carts with padlocks, it is impossible to control when it was last opened and who is responsible for its verification and closing. It is also impossible to guarantee the safety of the equipment within the cart, such as psychotropic medication. During a CPA, if the key to open the lock cannot be found, treatment will suffer significant delay, putting the patient's life at risk ${ }^{(14)}$.

An appropriate environment for $\mathrm{CC}$ transportation is as important as the arrangement and organization of its equipment. Although these do not seem to be priority items, being commonly unnoticed, they may impact directly the time for CPA treatment when co-occurring ${ }^{(14)}$.
The purpose of mobile cabinets, such as crash carts, is the easy access to equipment during the treatment by the staff in units. The excess of equipment and the lack of an identification for drawers and compartments hinder a quick and precise localization of the equipment to be employed ${ }^{(18)}$. Also, such excess reduces the space for organizing other equipment, which is often hard to identify within the drawer. The drawer should hold the minimal equipment required by institutional protocol in an ordered manner; unnecessary items should be removed and only the indispensable ones should be stored ${ }^{(16)}$. All drawers should have visible identification through which items of each compartment are classified for quick access ${ }^{(14)}$.

For units with the appropriate amount of equipment and with due drawer identification, the difference during verification was noticeable. When opening a drawer, it was possible to quickly find equipment; in addition to helping with the time until response to CPA, this also facilitates the team's work of checking and replacing items, since, during duty, optimizing time is of utmost importance ${ }^{(14)}$.

Excess equipment in the $\mathrm{CC}$ also impacts waste, since this may remain unused and expire; thus, it is appropriate that certain equipment stay in the nursing station, where they are used more often, and that only the amount necessary for emergency treatment be kept in the $\mathrm{CC}^{(19)}$.

The defibrillator is a first priority item, i.e., it should be immediately present for CPA treatment, because early defibrillation is one of the determinant factors for CPR success $^{(20)}$. Daily control of the equipment is thus required. Nurses are legally responsible for maintenance and control of items inside the CC, including control of defibrillator functionality ${ }^{(21)}$. The defibrillator test varies according to the manufacturer's model and thus the nurse should follow the instructions recommended by the manual ${ }^{(13)}$. In addition to daily control, it is necessary that the defibrillator is continuously connected to the power line so that, when moving to the bed/place where a CPA occurs, a device sufficiently charged to provide treatment is available to the team, with no need of being connected to the power line, increasing mobility and improving treatment dynamics ${ }^{(7)}$.

In addition to the defibrillator, SBC also classifies the hand resuscitator as a first priority item. The hard board is not in the checklist proposed by SBC, but cardiac compression is emphasized to be effective only when the patient's thorax is over a rigid surface. Compressions are suggested to start as soon as possible; thus, the hard board should be immediately present when CPR starts ${ }^{(11)}$.

Medication errors, caused by incorrect storage and identification, may lead to irreversible damage to the patient. Since nursing is in the front line of care, considering that it organizes, prepares, and administers medication, guaranteeing that patients receive safe assistance is part of its legal responsibility ${ }^{(22)}$. For such, during an emergency event, the medication drawer is required to contain visible divisions and labels for its organization; also, medication should not be expired ${ }^{(2)}$. Medications due to expire within three months should be substituted, except when unavailable in the hospital. In this specific case, it is possible to keep them in the CC until their expiration date and replace them as soon as possible ${ }^{(13)}$. 
To guarantee safe treatment, it is necessary to periodically check the $\mathrm{CC}$ to make sure that medications are in their due compartments and not expired, avoiding errors during administration $^{(7)}$. This indicates the importance of a checklist for verifying items and controlling equipment quantity, integrity, and expiration, so as to replace it and guarantee that, during CPR maneuvers, all equipment is present and fit for use ${ }^{(2,14)}$. In addition to providing due identification and verifying medication, it is crucial that the multiprofessional team are familiar with the $\mathrm{CC}$ and participate in constant updates on patient treatment in acute situations ${ }^{(14)}$.

Mannitol is a third priority item, i.e., its storage in the $\mathrm{CC}$ is recommended, although not mandatory ${ }^{(23)}$. This is a diuretic whose mechanism of action consists in preventing tubular water absorption and improving sodium excretion, increasing the glomerular filtrate's osmotic concentration. It is indicated mainly to promote diuresis when needed for reducing intracranial and intraocular pressure, as well as brain edema $^{(19)}$. Safety measures for vial storage include observing whether solutions tend to form crystals, in which case they cannot be administered to the patient. They should present a clear, hypotonic, sterile, non-pyrogenic liquid aspect. Not replacing the solution for others which are fit for use may lead to administering solutions with crystals, causing damage to patients ${ }^{(19)}$.

This research was limited by its conduction in medium and large sized hospitals of a particular region. Further research is suggested to broaden such parameters to include other hospitals and possibly suggest crash cart standardization.

The scarcity of up-to-date literature on recommendations for crash carts and of research showing the impacts of the consequences of their inadequacies was an obstacle to performing a comparative analysis departing from this study's data.

\section{CONCLUSION}

The most relevant factors to possibly interfere with the operational conditions of crash carts are directly related to the organization and management of material resources, which may lead to a reduction in their functionality during patient treatment. Such factors can be mostly solved with readjustment of the items, as well as frequent verification. This study can thus contribute to the organization of nursing treatment in clinical and surgical units, whose management processes depend directly on nurses.

\section{RESUMO}

Objetivo: Avaliar as condições operacionais de carros de emergência em todas as unidades de internação clínicas e cirúrgicas em hospitais públicos de uma região no sul do Brasil. Método: Estudo quantitativo transversal que avaliou carros de emergência em unidades de internação clínica e cirúrgica adulto. Os dados foram coletados por meio de checklist contendo 16 variáveis contínuas. Resultados: Foram avaliados 19 carros de emergência em 19 unidades. Na análise, os problemas com maior ocorrência foram: excesso de materiais e sua falta de organização, medicações em divisórias trocadas e/ou sem identificação e ambiente inadequado para o transporte. Conclusão: Os fatores mais relevantes que podem interferir nas condições operacionais dos carros de emergência estão diretamente ligados à organização e gestão dos recursos materiais, que podem levar à diminuição da sua funcionalidade durante o atendimento ao paciente. Tal problema pode ser solucionado com readequação dos itens e conferências frequentes.

\section{DESCRITORES}

Parada Cardíaca; Reanimação Cardiopulmonar; Enfermagem em Emergência; Equipamentos e Provisões.

\section{RESUMEN}

Objetivo: Evaluar las condiciones de funcionamiento de los carros de paradas en todas las unidades de hospitalización clínica y quirúrgica de los hospitales públicos de una región del sur de Brasil. Método: Estudio cuantitativo, transversal que evaluó los carros de paradas en las unidades de hospitalización clínica y quirúrgica de adultos. Los datos se recogieron mediante un checklist que contenía 16 variables continuas. Resultados: Se evaluaron 19 carros de paradas en 19 unidades. En el análisis, los problemas más frecuentes fueron el exceso de materiales y su falta de organización, la medicación en tabiques cambiados y/o sin identificación, y un entorno inadecuado para el transporte. Conclusión: Los factores más importantes que pueden interferir en las condiciones operacionales de los carros de paradas están directamente relacionados con la organización y la gestión de los recursos materiales, lo que puede llevar a la disminución de su funcionalidad durante la atención al paciente. Este problema puede resolverse con el reajuste de los materiales y verificaciones frecuentes.

\section{DESCRIPTORES}

Paro Cardiaco; Reanimación Cardiopulmonar; Enfermería de Urgencias; Equipos y Suministros.

\section{REFERENCES}

1. Iqbal MB, Al-Hussaini U, Rosser L, Salehi S, Phylactou H, Rajakulasingham R. Predictors of survival and favorable functional outcomes after an out-of-hospital cardiac arrest in patients systematically brought to a dedicated heart attack center (from the Harefield Cardiac Arrest Study). Am J Cardiol. 2015;115(6):730-7. doi: https://doi.org/10.1016/j.amjcard.2014.12.033

2. Barbosa V, Gomes E, Vaz S, Azevedo G, Fernandes G, Ferreira A, et al. Falha na ativação da equipe de emergência intra-hospitalar: causas e consequências. Rev Bras Ter Intensiva. 2016;28(4):420-26. doi: http://dx.doi.org/10.5935/0103-507x.20160075

3. Gomes AG, Garcia AM, Schmidt A, Mansur AP, Vianna CB, Ferreira D et al. Diretriz de apoio ao suporte avançado de vida em cardiologia - Código Azul - Registro de ressuscitação normatização do carro de emergência. Arq Bras Cardiol. 2003;81 Supl.4:3-14. doi: https://doi. org/10.1590/S0066-782X2003001800001

4. Manetti BKS, Amukugo HJ, Shilunga APK. Emergency trolley's contents and records: audit study at maternity sections, State Hospitals, Windhoek, Namibia. Op J Nurs. 2018;7(8):448-72. doi: https://doi.org/10.4236/ojn.2018.87035 
5. Crimlisk J, Doherty M, Fernandes E, Leblanc E, Guarino R, Costello K. Adult code cart redesign: clinical implications. Nursing. 2018;48(7):58-61. doi: https://doi.org/10.1097/01.NURSE.0000532760.94860.2e

6. Carvalho REFL, Arruda LP, Nascimento NKP, Sampaio RL, Cavalcante MLSN, Costa ACP. Assessment of the culture of safety in public hospitals in Brazil. Rev Latino Am Enfermagem. 2017;25:e2849. doi: https://doi.org/10.1590/1518-8345.1600.2849

7. Citolino Filho CM, Santos ES, Silva RCE, Nogueira LDS. Factors affecting the quality of cardiopulmonary resuscitation in inpatient units: perception of nurses. Rev Esc Enferm USP. 2015;49:907-13. doi: https://doi.org/10.1590/S0080-623420150000600005

8. Tsima BM, Rajeswaran L, Cox M. Assessment of cardiopulmonary resuscitation equipment in resuscitation trolleys in district hospitals in Botswana: a cross-sectional study. Afr J Prim Health C Fam Med. 2019;11(1):a2029. doi: https://doi.org/10.4102/phcfm.v11i1.2029

9. Maul E, Latham B, Westgate PM. Saving time under pressure: effectiveness of standardizing pediatric resuscitation carts. Hosp Pediatr. 2016;6(2):67-71. doi: https://doi.org/10.1542/hpeds.2015-0161

10. Nolan JP, Soar J, Cariou A, Cronberg T, Moulaert VRM, Deakin CD, et al. European Resuscitation Council and European Society of Intensive Care Medicine Guidelines for Post-resuscitation Care 2015 Section 5 of the European Resuscitation Council Guidelines for Resuscitation 2015. Resuscitation. 2015;95:202-22. doi: https://doi.org/10.1007/s00134-015-4051-3

11. Gonzalez MM, Timerman S, Oliveira RG, Polastri TF, Dalan LA, Araújo S, et al. I Diretriz de ressuscitação cardiopulmonar e cuidados cardiovasculares de emergência da Sociedade Brasileira de Cardiologia: resumo executivo. Arq Bras Cardiol. 2013;100(2):105-13. doi: https://doi.org/10.5935/abc.20130022

12. Jacquet GA, Hamade B, Diab KA, Sawaya R, Dagher GA, Hitti E, Bayram JD. The emergency department crash cart: a systematic review and suggested contents. World J Emerg Med. 2018;9(2):93-8. doi: https://doi.org/10.5847/wjem.j.1920-8642.2018.02.002

13. Takayama W, Endo A, Koguchi H, Otomo Y. Difference in the quality of cardiopulmonary resuscitation between day-time and night-time: a retrospective observational study. Ressucitation. 2018;130(1):e135-6. doi: https://doi.org/10.1016/j.resuscitation.2018.07.290

14. Hansen C, Lauridsen KG, Schmidt AS, Løfgren B. Decision-making in cardiac arrest: physicians' and nurses' knowledge and views on terminating resuscitation. Open Access Emerg Med. 2018;11:1-8. doi: https://doi.org/10.2147/OAEM.S183248

15. Nolan JP, Berg RA, Andersen LW, Bhanji F, Chan PS, Donnino MW, et al. Cardiac arrest and cardiopulmonary resuscitation outcome reports: update of the Utstein Resuscitation Registry Template for In-Hospital Cardiac Arrest: a consensus report from a task force of the International Liaison Committee on Resuscitation (American Heart Association, European Resuscitation Council, Australian and New Zealand Council on Resuscitation, Heart and Stroke Foundation of Canada, InterAmerican Heart Foundation, Resuscitation Council of Southern Africa, Resuscitation Council of Asia). Circulation. 2019;140(18):e746-57. doi: http://dx.doi.org/10.1161/CIR.0000000000000710

16. Raj A, Saini RS, Sing MM. Evaluation of availability and effectiveness of crash cart in public and PVT hospitals. Indian J Res. 2019;8(2):1-5.

17. Frota OP, Ferreira AM, Guerra OG, Rigotti MA, Andrade D, Borges NMA, et al. Efficiency of cleaning and disinfection of surfaces: correlation between assessment methods. Rev Bras Enferm. 2017;70(6):1176-83. doi: http://dx.doi.org/10.1590/0034-7167-2016-0608

18. Makkar N, Madaan N. Study of compliance of crash carts to standards in the emergency of a tertiary care teaching hospital. Int J Res Med Sci. 2016;4(9):3968-76. doi: http://dx.doi.org/10.18203/2320-6012.ijrms20162917

19. Oliveira ECS, Oliveira RC, Silva FP, Nunes CS. Padronização de fármacos em carros de emergência nas unidades de terapia intensiva e emergência. Rev Enf Ref. 2019;serIV(22):97-105. doi: http://dx.doi.org/10.12707/RIV19021

20. Silva RM, Silva BA, Silva FJ, Amaral CF. Ressuscitação cardiopulmonar de adultos com parada cardíaca intra-hospitalar utilizando o estilo Utstein. Rev Bras Ter Intensiva. 2016;28(4):427-35. doi: http://dx.doi.org/10.5935/0103-507x.20160076

21. Bowden, T, Smith, D. An overview of adult cardiopulmonary resuscitation equipment. Nurs Stand. 2016;31(23):54-63. doi: http://dx.doi. org/10.7748/ns.2017.e10461

22. Moura JG, Brito MPS, Rocha GOS, Moura LTR. Conhecimento e atuação da equipe de enfermagem de um setor de urgência no evento parada cardiorrespiratória. Rev Online Pesq Cuid Fundam. 2019;11(3):634-640. doi: http://dx.doi.org/10.9789/2175-5361.2019. v11i3.634-640

23. Mieiro DB, Oliveira EB, Fonseca RE, Mininel VA, Zem-Mascarenhas SH, Machado RC. Estratégias para minimizar erros de medicação em unidades de emergência: revisão integrativa. Rev Bras Enferm. 2019;72 Supl.1:307-14. doi: https://doi.org/10.1590/0034-7167-2017-0658 